\title{
Doubts of caregivers of children with cleft lip and palate on postoperative care after cheiloplasty and palatoplasty
}

\author{
DÚVIDAS DE CUIDADORES DE CRIANÇAS COM FISSURA LABIOPALATINA SOBRE OS \\ CUIDADOS PÓS-OPERATÓRIOS DE QUEILOPLASTIA E PALATOPLASTIA
}

\author{
DUDAS DE CUIDADORES DE NIÑOS CON FISURA LABIOPALATINA ACERCA DE LOS \\ CUIDADOS POSOPERATORIOS DE QUEILOPLASTIA Y PALATOPLASTIA
}

\section{Armando dos Santos Trettene ${ }^{1}$, Ana Paula Ribeiro Razera ${ }^{2}$, Thaís de Oliveira Maximiano ${ }^{3}$, Aline Godoi Luiz ${ }^{3}$, Gisele da Silva Dalben ${ }^{4}$, Marcia Ribeiro Gomide ${ }^{5}$}

\begin{abstract}
Objective: to identify the main doubts of caregivers of children with cleft lip and palate on postoperative care after cheiloplasty and palatoplasty. Method: crosssectional study carried out in a reference hospital, between September and November 2012. The sample was composed of 50 individuals divided in two groups, of which 25 caregivers of children submitted to cheiloplasty, and 25 of children submitted to palatoplasty. The doubts were identified by an interview applied during the preoperative nursing consultation and were then categorized by similarity. Descriptive statistics was used for analysis of the outcomes. Results: Concerning cheiloplasty, the doubts were related to feeding (36\%), hygiene and healing ( $24 \%$ each), pain and infection ( $8 \%$ each). With regard to palatoplasty, the doubts were related to feeding (48\%), hygiene $(24 \%)$, pain (16\%), bleeding (8\%) and infection (4\%). Conclusions: The study evidenced the concern of caregivers in relation to feeding and care of the postoperative wound.
\end{abstract}

\section{RESUMO}

Objetivo: Identificar as principais dúvidas dos cuidadores de crianças com fissura labiopalatina sobre os cuidados pós-operatórios das cirurgias de queiloplastia e palatoplastia. Método: Estudo transversal realizado em um hospital de referência, entre os meses de setembro a novembro de 2012. A amostra constou de 50 indivíduos divididos em dois grupos, sendo 25 cuidadores de crianças submetidas à queiloplastia e 25 crianças submetidas à palatoplastia. As dúvidas foram identificadas por meio de entrevista, realizada durante a consulta de Enfermagem pré-operatória, e, posteriormente, foram categorizadas por similaridade. Utilizou-se a análise estatística descritiva para construção dos resultados. Resultados: Observou-se que, em relação à queiloplastia, as dúvidas foram sobre alimentação (36\%), higienização e cicatrização ( $24 \%$ cada), e dor e infecção ( $8 \%$ cada). Quanto à palatoplastia, as dúvidas se relacionaram à: alimentação (48\%), higienização (24\%), dor (16\%), sangramento (8\%) e infecção (4\%). Conclusão: Evidenciou-se a preocupação dos cuidadores em relação à alimentação e aos cuidados com a ferida pós-operatória.

\section{RESUMEN}

Objetivo: Identificar las principales dudas de los cuidadores de niños con fisura labiopalatina acerca de los cuidados posoperatorios de las cirugías de queiloplastia y palatoplastia. Método: Estudio transversal llevado a cabo en un hospital de referencia, entre los meses de septiembre a noviembro de 2012. La muestra constó de 50 individuos divididos en dos grupos, siendo 25 cuidadores de niños sometidos a la queiloplastia y 25 niños sometidos a la palatoplastia. Las dudas fueron identificadas por medio de entrevista, realizada durante la consulta de Enfermería preoperatoria y, posteriormente, fueron categorizadas por similaridad. Se utilizó el análisis estadístico descriptivo para la construcción de los resultados. Resultados: Se observó que, con respecto a la queiloplastia, las dudas fueron acerca de la alimentación (36\%), higienización y cicatrización ( $24 \%$ cada), y dolor e infección ( $8 \%$ cada). En cuanto a la palatoplastia, las dudas estuvieron relacionadas con: la alimentación (48\%), higienización $(24 \%)$, dolor $(16 \%)$, sangrado $(8 \%)$ e infección (4\%). Conclusión: Se evidenció la preocupación de los cuidadores con respecto a la alimentación y los cuidados con la herida posoperatoria.

\author{
DESCRIPTORES \\ Labio leporino \\ Fisura del paladar \\ Periodo postoperatorio \\ Cuidadores \\ Enfermería pediátrica
}

\author{
Cleft lip \\ Cleft palate \\ Postoperative period \\ Caregivers \\ Pediatric nursing
}

DESCRITORES

Fissura palatina

Período pós-operatório

Enfermagem pediátrica

${ }^{1} \mathrm{PhD}$ student in Rehabilitation Sciences, Hospital for Rehabilitation of Craniofacial Anomalies, University of São Paulo, Brazil. ${ }^{2}$ PhD student in Rehabilitation Sciences, Hospital for Rehabilitation of Craniofacial Anomalies, University of São Paulo, Brazil. ${ }^{3}$ Nurse. Postgraduate student (Multiprofessional Residency in Health: Syndromes and Craniofacial Anomalies, Hospital for Rehabilitation of Craniofacial Anomalies, University of São Paulo, Brazil. ${ }^{4}$ PhD in Oral Pathology, Hospital for Rehabilitation of Craniofacial Anomalies, University of São Paulo, Brazil. ${ }^{5}$ PhD in Pediatric Dentistry, Hospital for Rehabilitation of Craniofacial Anomalies, University of São Paulo, Brazil. 


\section{INTRODUCTION}

Cheiloplasty and palatoplasty are the first reconstructive plastic surgeries performed during the long and complex treatment of cleft lip and palate. For children born with clefts, the reconstructive surgery is not only an esthetical challenge, but mainly functional. Cheiloplasty is the surgery for lip repair, while palatoplasty aims at reconstructing the palatal cleft ${ }^{(1)}$.

Children submitted to cheiloplasty and palatoplasty should be discharged from hospital when their caregivers are able to provide after-surgery care, since treatment success is directly related to an effective nursing care ${ }^{(2)}$. This teaching-learning process should occur systematically, since hospital discharge takes place approximately 24 hours after the surgical procedure ${ }^{(3)}$.

In addition to implications inherent to the surgical procedure, the postoperative period is a favorable moment for the nursing training the caregivers on after-surgery care, in order to maintain it even after hospital discharge, including prevention of bleeding, pain control, feeding and hydration, physical restraint and care with the surgical wound.

Nurses are responsible for guiding and solving doubts related to the care, offering reassurance and safety, providing a holistic and humanistic care not only to individuals, but also to their families ${ }^{(3-4)}$.

The training of caregivers on postoperative care should be initiated preoperatively, since the elucidations related to surgeries, in addition to learning, contribute to reduce the anxiety of caregivers, who usually face high physical and psychological distress, thus facilitating the situational coping $^{(3)}$. Therefore, the nurse plays a fundamental role in all stages of rehabilitation of children with cleft lip and palate, acting in the training of individuals and/or caregivers.

It is fundamental to diagnose the doubts of caregivers on postoperative care, to allow the planning and establishment of educational actions, aiming to minimize complications, favor the rehabilitation process and reduce the costs to the health system.

Therefore, arises the question: what are the main doubts of caregivers of children with cleft lip and palate concerning the postoperative care after cheiloplasty and palatoplasty? T he lack of publications on this subject highlights the relevance of the present study.

Therefore, this study aimed to identify the main doubts of caregivers of children with cleft lip and palate about the postoperative care after cheiloplasty and palatoplasty.

\section{METHOD}

This cross-sectional study was carried out in a reference hospital between September and November 2012.
The study was approved by the Institutional Review Board (protocol n. 109093); the participants were informed on the study objectives and agreed to participate by signing an informed consent form.

The sample was composed of caregivers of children with cleft lip and palate submitted to cheiloplasty and palatoplasty. Intentional sampling was obtained and comprised 50 caregivers consecutively selected, of which 25 caregivers of children submitted to cheiloplasty, and 25 of children submitted to palatoplasty, regardless of age, gender and socioeconomic level. Caregivers of children with neuropsychomotor disorders, genetic syndromes and other malformations or comorbidities that required special care were excluded.

Data were collected during the preoperative nursing consultation. During this consultation, the nurse addressed aspects related to preparation for the surgical procedure, including checking of fasting period, overall status of the individual, events in the 24 previous hours, previous pathologies, use of drugs, need of medical evaluation, expectations on the surgical procedure and the main doubts related to the postoperative period.

Data were collected using a structured interview. The doubts were described in a form prepared by the investigators and then categorized according to similarity. Data were exclusively collected by the investigators to avoid biases. The participants were characterized according to kinship, age, educational level, marital status and socioeconomic level. Possible correlations between the doubts and the variables found were not analyzed in this study, since cheiloplasty and palatoplasty are primary surgeries, i.e. the caregivers had no previous experience.

For stratification of the outcomes, data were analyzed by descriptive statistics (relative and absolute frequency).

\section{RESULTS}

The mean age of interviewees was 23 years ( \pm 1.8 ), $43 \%(n=23)$ reported to have concluded high school and there was predominance of low socioeconomic level $(62 \%, n=31)$. Concerning the marital status, there was predominance of cohabitation $(68 \%, n=34)$. In relation to kinship of caregivers, $90 \%(n=45)$ were the mothers.

The doubts of caregivers on postoperative care after cheiloplasty and palatoplasty were related to the following items: consistence of foods, utensils used for feeding, types of food to be offered, technique for cleaning the surgical wound, accomplishment of oral hygiene, utilization of oral antiseptics, time for stitch removal, sun exposure, arm restraints, signs and symptoms of pain, analgesics that should be used and recognition of atypical bleeding.

The doubts were categorized according to similarity (Table 1). For both cheiloplasty and palatoplasty, there
Doubts of caregivers of children with cleft lip and palate on postoperative care after cheiloplasty and palatoplasty Trettene AS, Razera APR, Maximiano TO, Luiz AG, Dalben GS, Gomide MR 
was predominance of doubts about feeding $(96 \%$ and $100 \%$, respectively).

Table 1 - Distribution of doubts of caregivers about the postoperative period after cheiloplasty and palatoplasty Bauru, SP, 2012

\begin{tabular}{lcc}
\hline Variables & Cheiloplasty & Palatoplasty \\
\hline Feeding & $96 \%$ & $100 \%$ \\
Hygiene & $88 \%$ & $92 \%$ \\
Healing & $88 \%$ & - \\
Infection & $72 \%$ & $52 \%$ \\
Bleeding & - & $76 \%$ \\
Pain & $60 \%$ & $84 \%$ \\
\hline
\end{tabular}

\section{DISCUSSION}

The adequate training of caregivers of children with cleft lip and palate is challenging to the nursing team, since the quality of care provided directly influences the rehabilitation process ${ }^{(5-6)}$. Emphasis has been given to the need to develop systematic nursing care programs, in order to meet the international standards of safety and achieve efficacy of outcomes ${ }^{(7)}$.

The nurse should identify the lacunae in knowledge and suggest interventions to minimize or solve the doubts and fears of caregivers. The realization of cheiloplasty and/or palatoplasty implies on the need of specific care and represents a moment of high stress for both children submitted to surgery and their caregivers ${ }^{(2)}$.

The prevailing doubt in relation to the postoperative care after cheiloplasty and palatoplasty was related to feeding, including types of food to be offered, their consistence and administration method. The concern with feeding the children with cleft lip and palate is present since birth, due to involvement of the oral cavity ${ }^{(8-9)}$.

The adequate food acceptance significantly interferes with the postoperative recovery, being also related to the healing process and prevention of infections ${ }^{(10)}$.

Food should be offered as soon as the child awakes after the anesthetic-surgical procedure, provided there are no postoperative complications. At this moment, the diet should be liquid and cool; should be prepared using foods according to the child's age; include fruits blended with milk, water or juice, vitamins and soups; and should be offered in a glass or spoon ${ }^{(3)}$.

Even though feeding after cheiloplasty using the bottle is widely accepted, its use after palatoplasty is contradictory, because this is the most invasive surgical procedure among primary surgeries. The child may not satisfactorily accept feeding by the bottle, leading to greater weight loss ${ }^{(11-12)}$.

In addition to the bottle, other utensils that require suction, such as nipples, pacifiers and straws, should be avoided to prevent harm to the surgical site. Within this context, the glass and spoon are viable alternatives due to their low cost, easy handling and hygiene. A study ${ }^{(3)}$ compared the food acceptance of children in the immediate postoperative period after palatoplasty using glass and spoon, and evidenced that children fed with the spoon accepted greater volume in shorter time, with fewer cases of cough and choking and less food loss through the lip commissure.

Another study conducted to identify the feeding practices among children with cleft lip and palate in different age ranges concluded that spoon feeding was the most common feeding method ${ }^{(13)}$.

Other utensils are described in the literature as alternatives for child feeding after cheiloplasty and palatoplasty, including syringes, tubes and droppers. However, these are not often used anymore, and their utilization is associated with lack of information. The utilization of tubes is contraindicated, because the suction and swallowing reflexes are preserved. Notwithstanding, another study ${ }^{(14)}$ reported that children fed through the nasogastric tube require less analgesics in the postoperative period after palatoplasty, inferring less pain.

A study (1992) compared the feeding using tube and syringe, breastfeeding and bottle feeding, in the postoperative period after cheiloplasty and palatoplasty, and did not observe significant differences from nutritional, immunological and psychological standpoints ${ }^{(11)}$. Conversely, another study evaluated the feeding of children submitted to cheiloplasty comparing direct breastfeeding and the spoon, and concluded that breastfed children had greater weight ${ }^{(15)}$.

Even though the syringe is indicated as a feeding method for children with cleft lip and palate, its benefits have been reported as a feeding alternative only for newborns ${ }^{(16)}$. The utilization of syringe is contraindicated in the postoperative period because of the risk of trauma to the surgical wound and difficult handling by the caregiver(3).

A study evaluated the nutritional status and complications of the surgical wound in the postoperative period after cheiloplasty in children fed through bottle and spoon. It concluded that in both groups the outcomes were positive and similar, suggesting the use of bottle feeding for children in the postoperative period after cheiloplasty $^{(17)}$. Considering the several options of utensils for child feeding after cheiloplasty and palatoplasty, it is important to highlight that different utensils than those routinely used, besides unnecessary, contribute to increase the stress of both the child and the caregiver ${ }^{(3)}$.

Another doubt reported by caregivers was related to hygiene of the surgical wound. In both surgeries, oral hygiene is the main factor for prevention of infection. For cheiloplasty, in addition to toothbrushing and 
mouthrinsing with aqueous solutions, it is fundamental to clean the surgical wound before and after meals, and whenever there is secretion or food rests at the surgical site, using cotton swabs soaked in saline or filtered water ${ }^{(18)}$. For palatoplasty, oral hygiene is performed by careful toothbrushing avoiding harm to the surgical wound and mouthrinsing with oral antiseptics after each meal and before sleep ${ }^{(19)}$. Children unable to breastfeed may be offered water, tea or juice after each meal(18).

With regard to the postoperative healing process, the cheiloplasty stitches should be removed as indicated by the surgeon, usually after seven to ten days. Concerning palatoplasty, the stitches and/or tampons are spontaneously eliminated after 20 to 30 days, thus not requiring removal. Direct exposure to the sun should be avoided for six months after surgery, because it interferes with the healing process. The use of sunscreen is indicated.

Concerning the infection prevention, in addition to the need to intensify the oral hygiene and use prophylactic antibiotics transoperatively and in the immediate postoperative period, the caregiver should be attentive to the classical signs of infection, including the presence of secretion, malodor, dehiscence and fever ${ }^{(1)}$.

Another questioning referred to postoperative pain control. Pain is one of the most frequent complications in the immediate postoperative period after cheiloplasty and palatoplasty, and the caregivers should be attentive to suggestive signs and symptoms, including facial expression (grimace), posture (defense) and focus (crying or moaning) $)^{(1)}$. Cheiloplasty is usually performed before 12 months of age, when the verbal response is impaired. Analgesics should be routinely administered in the first 24 hours after surgery, and as needed thereafter. Special care should be given to analgesics that induce respiratory depression.

Bleeding control was also indicated as a concern by caregivers. The anatomical regions of the cheiloplasty and palatoplasty are highly vascularized, and the risk of bleeding is always present. Bleeding is often associated with traumatic events, usually caused by playing with acute objects, hitting against the cradle grid or even against the caregiver's shoulder. Revision for hemostasis may be necessary in extreme cases.

The utilization of arm restraints is recommended mainly during sleep, when the child voluntarily or involuntarily places the hand in the mouth, possibly causing trauma to the surgical site, evolving to hemorrhage. Therefore, it is extremely important to guide the caregivers to look for immediate medical care in case of bleeding, due to the possible hemodynamic consequences.

This evidences the importance of nursing counseling, as well as the development of strategies for that purpose, to promote the care, prevent and/or minimize the problems related to the postoperative period. The utilization of new tools, for example including educational videos and other didactic materials, as booklets and leaflets, has been suggested to aid the promotion of training of caregivers. However, the outcomes are directly related to the quality of materials, which should be designed by highly experienced professionals ${ }^{(20)}$.

There is consensus that surgeries for cleft lip and palate repair should be performed in multidisciplinary centers. A study carried out to evaluate institutions providing care for individuals with cleft lip and palate, concerning the adherence to recommendations of a competent institution, concluded that there was a centralization of services in the last decade, yet it was not possible to evaluate the efficacy in relation to better outcomes $^{(21)}$. However, at national level, there is a tendency of decentralization. Within this context, emphasis is given to the need of greater diffusion of postoperative care measures among health professionals, since after hospital discharge the individuals and their families return to their cities of origin, often without support in their communities, facing difficulties related to postoperative complications due to lack of knowledge.

A study aiming to define the strategies related to the training of caregivers on postoperative care after cheiloplasty and palatoplasty concluded that home care was effective for that purpose, recommending its utilization. It also concluded that the families felt supported and satisfied, besides mentioning greater reassurance to perform the postoperative care $^{(22)}$.

It should be mentioned that data collection during the preoperative consultation might be considered a limiting factor of the present study, since the common high level of stress among caregivers in this period may have influenced the outcomes to some extent.

Some services are available in our institution, such as the elucidation of doubts on postoperative complications by telephone. The limited knowledge among health professionals about the care of individuals with cleft lip and palate is a great reality and a great challenge $\mathrm{e}^{(23-24)}$.

\section{CONCLUSION}

We believe that this study contributed to identify the main doubts of caregivers on postoperative care after cheiloplasty and palatoplasty, allowing the planning and establishment of nursing care targeted to the needs of this population. The prevailing doubts were related to feeding and care of the surgical wound. This evidenced the important role of nurses as promoters of care, and of using the preoperative and postoperative periods to train the caregivers for maintaining the care after hospital discharge. Additionally, there is the need to design effective educational materials and develop strategies of postoperative monitoring.
Doubts of caregivers of children with cleft lip and palate on postoperative care after cheiloplasty and palatoplasty Trettene AS, Razera APR, Maximiano TO, Luiz AG, Dalben GS, Gomide MR 


\section{REFERENCES}

1. Biazon J, Peniche ACG. Retrospective study of postoperative complications in primary lip and palate surgery. Rev Esc Enferm USP. 2008;42(3):511-7.

2. Augsornwan D, Pikhunthod K, Pongpagatip S, Surakunprapha P. Nursing outcome in patients with cleft lip and palate who underwent operation: follow-up cases. J Med Assoc Thai. 2012;95 Suppl 11:S116-20.

3. Trettene AS, Mondini CCDS, Marques IL. Feeding children in the immediate perioperative period after palatoplasty: a comparison between techniques using a cup and a spoon. Rev Esc Enferm USP. 2013;47(6):1298-1304.

4. Pradubwong S, Pongpagatip S, Volrathongchai K, Chowchuen $B$. The development of the nursing care system for patients with cleft lip-palate and craniofacial deformities at Tawanchai Cleft Center, Srinagarind Hospital, KhonKaen, Thailand. J Med Assoc Thai. 2012;95 Suppl 11:S55-61.

5. Nusbaum R, Grubs R, Losee JE, Weidman C, Ford MD, Marazita ML. A qualitative description of receiving a diagnosis of clefting in the prenatal or postnatal period. J Genet Couns. 2008;17(4):336-50.

6. Pongpagatip S, Pradubwong S, Jenwitheesuk K, Chowchuen B. Knowledge and satisfaction of caregivers of patients with cleft lip-palate at the Tawanchai Cleft Center. Plast Surg Nurs. 2012;32(4):165-70.

7. Riratanapong S, Sroihin W, Kotepat K, Volrathongchai K. Nursing care system development for patients with cleft lip-palate and craniofacial deformities in operating room Srinagarind Hospital. J Med Assoc Thai. 2013;96(4):44-8.

8. Gil-da-Silva-Lopes VL, Xavier AC, Klein-Antunes D, Ferreira AC, Tonocchi R, Fett-Conte AC, et al. Feeding infants with cleft lip and/or palate in Brazil: suggestions to improve health policy and research. Cleft Palate Craniofac J. 2013;50(5):577-90.

9. Smedegarrd L, Marxen D, Moes J, Glassou EN, Scientsan C. Hospitalization, breast-milk feeding, and growth in infants with cleft palate and cleft lip and palate born in Denmark. Cleft Palate Craniofac J. 2008;45(6):628-32.

10. Silva EB, Rocha CMG, Lage RR. O bebê com fissura labiopalatina: intervenção interdisciplinar. In: Jesus MSV, Di Ninno CQMS, coordenadores. Fissura labiopalatina: fundamentos para a prática fonoaudiológica. São Paulo: Roca; 2009. p. 10-28.

11. Cohen M, Marschall MA, Schafer ME. Immediate unrestricted feeding of infants following cleft lip and palate repair. J Craniofac Surg. 1992;3(1):30-2.
12. Kim EK, Lee TJ, Chae SW. Effect of unrestricted bottle-feeding on early postoperative course after cleft palate repair. J Craniofac Surg. 2009;20(2):1886-8.

13. Goyal A, Jena AK, Kaur M. Nature of feeding practices among children with cleft lip and palate. J Indian Soc PedodPrev Dent. 2012;30(1):47-50.

14. Kent R, Martin V. Nasogastric feeding for infants who have undergone palatoplasty for a cleft palate. Paediatr Nurs. 2009;21(10):24-9.

15. Darzi MA, Chowdri NA, Bhat AN. Breast feeding or spoon feeding after cleft lip repair: a prospective. Br J Plast Surg. 1996;49(1):24-6.

16. Ize-lyamu IN, Saheeb BD. Feeding intervention in cleft lip and palate babies: a practical approach to feeding efficiency and weight gain. Int J Oral Maxillofac Surg. 2011;40(9):916-9.

17. Assunção AG, Pinto MA, Peres SP, Tristão MT. Immediate postoperative evaluation of the surgical wound and nutritional evolution after cheiloplasty. Cleft Palate Craniofac J. 2005;42(4):434-8.

18. Ribeiro EM, Moreira ASC. Atualização sobre o tratamento multidisciplinar das fissuras labiais e palatinas. Rev Bras Promoção Saúde. 2005;18(1):31-40.

19. Franco D, Eyler AD. Cirurgia de fissurados: detalhes que facilitam. Rev Soc Bras Cir Plast. 2003;18(1):55-69.

20. Augsornwan D, Pattangtanang P, Pikhunthod K. Nursing care system development for patients with cleft lip-palate and craniofacial deformities in Srinagarind Hospital: pre-post operation. J Med Assoc Thai. 2011;94(6):114-7.

21. Scott JK, Leary SD, Ness AR, Sandy JR, Persson M, Kilpatrick $\mathrm{N}$, et al. Centralization of services for children born with orofacial clefts in the United Kingdom: a cross-sectional survey. Cleft Palate Craniofac J. 2014;51(5):e102-9.

22. Augsornwan D, Pradubwong S, Prathumwiwattana P, Sucontaman D, Surakunprapha P. Home visit patients and family with cleft lip and palate. J Med Assoc Thai. 2011;94 Suppl 6:S109-13.

23. Vanz AP, Ribeiro NR. Listening to the mothers of individuals with oral fissures. Rev Esc Enferm USP. 2011;45(3):596-602.

24. Britton KF, McDonald SH, Welbury RR. An investigation into infant feeding in children born with a cleft lip and/ or palate in the West of Scotland. Eur Arch Paediatr Dent. 2011;12(5):250-5. 